The Journal of Public Space

ISSN 2206-9658

2019 | Vol. 4 n. 4

https://www.journalpublicspace.org

\title{
EDITORIAL
}

\section{Urban Commons and the Right to the City}

\author{
Manfredo Manfredini \\ University of Auckland, New Zealand \\ Faculty of Creative Arts and Industries \\ m.manfredini@auckland.ac.nz
}

In the increasing cosmopolitan condition of our cities inclusionary urban commons are becoming more and more relevant as civic institutions for encounter, dialogue and collaboration. Their non-commodifiable asset experiences increasing issues of social inclusion, participation, privatisation and universal access. The papers included in this issue of The Journal of Public Space are focused on the development of the commons' capacity firstly to contingently relate and articulate heterogeneous values and paradigms, personalities, spheres of thought and material and intangible elements; secondly to sustain equity, diversity, belonging by transforming conflicts in productive associations that counter conditions of antagonism to set up critically engaged agonistic ones (Connolly, 1995; Mouffe, 1999, 2008). They include analytical studies, critical appraisals and creative propositions-part of which documenting the City Space Architecture's event at Freespace, the $16^{\text {th }}$ Venice Architecture Biennale-which address the power of the inclusionary urban commons to support the constitution of free, open and participatory networks that enhance social, cultural and material production of urban communities by reclaiming, defending, maintaining, and taking care of the "coming together of strangers who work collaboratively [...] despite their differences" (Williams, 2018: 17).

The community production discussed in this issue is crucial for the political mobilization aimed at the reappropriation of the urban space that has been alienated, financialised and controlled by closed circles of expert managers (Butler, 20I2: I4I-I43). It concerns and integrates multiple spheres that construct a safe, healthy, resilient, pluralistic, and democratic society founded on principles of freedom, equality and solidarity (Borch \& Kornberger, 2015; Flusty, 1997: II; Garnett, 2012: 2012-2018): the civic realm that includes justice, law, and morality of the political, the economic domain that encompasses trade and exchange of goods and services, and finally the epistemological field for intercultural intellectual engagement and discourse. By forming context-specific organisational formats, this production enables "self-forming publics to appear, to represent themselves, to be represented" (Mitchell, 2017: 513) in an integral socio-spatial relationality that promotes citizens' participation, responsibilisation and conscious decision making (Villa, 1992). These processes sustain effectively collectivities in the everyday query for political identity and affirmation of citizenship, liberating their relationality from externally imposed constraints. They empower both local and translocal communities in their own relevant contexts, balance power structures and strengthen the exercises of the 
fundamental ontogenetic right of citizens to participate in the creation of their own material, cultural, and social spaces, both at the individual and associated levels.

The discussion of problems affecting urban commons has progressively grown in the last three decades and concentrated on the critique on the decay of their public agency (Hardt \& Negri, 2009; Harvey, 20 I I, 20 I 2; Kristjansdottir \& Sveinsson, 2016; Lefebvre, I99 I [1974], 1996; Manfredini, 2017, 2019; McQuire, 2008; Purcell, 2002, 20I4; Stanek, 20II; Susser \& Tonnelat, 2013; Sennett, 1977, 2008, 2018; United Nations, 2017). Fundamental references in this discussion are theories on the modern crisis of political sphere and citizenship rights that have addressed how the market economy has transformed public space into a pseudo-space of interaction (Arendt, 1958) and how the passive culture of consumption has led the state and private sectors to colonise the public sphere and alienate citizens from their political dimension (Calhoun, 1992; Habermas, 1991 [1962]). Key elaborations have addressed the specificity of the contemporary urban condition of increased segmented publics and counterpublics (Benhabib, 2000; Fraser, 1990; Harvey, 2007) with critical stances individually articulating crucial questions concerning spatial control (Dehaene \& De Cauter, 2008a, 2008b; Foucault 1995; Harvey, 2003), privatisation (Dawson, 2010; Lee and Webster, 2006; Low, 2006; Minton, 2012; Soja, 2010;), spatial justice (Low \& Smith 2006; Mitchell, 2003), socio-spatial segmentation (Dawson, 2010; Harvey, 2003; Hodkinson, 2012), consumption and alienation (Debord, 1983 [1967]; Firat \& Venkatesh, 1995; Miles \& Miles, 2004), and selective deprivation of public space (Davis, 1990; Harvey, 2003; Mitchell, 1995, 2003; Sorkin, 1992).

Furthering this discussion, the articles of this issue provide innovative insights into one of the major socio-spatial challenges to urban-resilience building, the test related to the recent transformation of the socio-spatial and technological frameworks of the commons: the development of both physical and functional redundancy in emerging mobile and digitally augmented spatialisation patterns of associative collaboration, vis-à-vis the augmented vulnerability of their infrastructure, consequent to its expanded control, displacements and financialisation. Arguing that their novel spatialisation patterns have the potential to make the commons bounce forward from the crisis caused by the withdrawal of direct state involvement and their subsequent private colonisation, these papers disentangle the complex changes in power relations that affect the exercise of the Right to the City (Harvey, 2008; Lefebvre, 1996 [1968]; Purcell, 2002) and the related Right to Difference, shedding light on the capacity of urban communities to reverse the decay of their own political agency and gain full control their production processes and protocols in the pursuit of an open, pluralistic and collaborative Freespace for the sustainable development of the physical, social and cultural dimensions of our cities.

\section{References}

Arendt, Hannah (1958). The Human Condition, Chicago: University of Chicago.

Benhabib, Sheila (2000). The reluctant modernism of Hannah Arendt, Thousand Oaks: Sage.

Borch, Christian and Kornberger, Martin (eds.) (2015). Urban commons: Rethinking the city, Abingdon, Oxon: Routledge.

Butler, Chris (20I2). Henri Lefebvre: Spatial Politics, Everyday Life, and the Right to the City, New York and London: Routledge. 
Calhoun, Craig (1992) Introduction: Habermas and the public sphere, in Habermas and the public sphere. Studies in contemporary German social thought, ed. Craig Calhoun, Cambridge, MA, MIT Press, I-50.

Connolly, W. E. (1995). The ethos of pluralization, Minneapolis: University of Minnesota Press.

Davis, Mike (1990). City of quartz: Excavating the future in Los Angeles, New York: Verso.

Dawson, Ashley (2010). Introduction: New enclosures, New Formations, 69, 8-22.

Debord, Guy (1983 [1967]). Society of the spectacle, Detroit: Black \& Red.

Dehaene Michiel and De Cauter, Lieven (2008a). Heterotopia in a postcivil society, in Heterotopia and the city: Public space in a postcivil society, ed. Michiel Dehaene and Lieven De Cauter, Abingdon, Oxon: Routledge, 3-9.

Dehaene Michiel and De Cauter, Lieven (2008b). Notes, in Heterotopia and the City: Public Space in a Postcivil Society, ed. Michiel Dehaene and Lieven De Cauter, Abingdon, Oxon: Routledge, 2229.

Firat, A. Fuat \& Venkatesh, Alladi (1995). Liberatory postmodernism and the reenchantment of consumption, Journal of Consumer Research, 22, 3: 239-267.

Flusty, S. (1997). Building paranoia, in Architecture of fear, ed. Nan Ellin, New York: Princeton Architectural Press. 47-59.

Foucault, Michel (1995). Discipline and punish: The birth of the prison, New York, Vintage Books.

Fraser, Nancy (1990). Rethinking the public sphere: A contribution to the critique of actually existing democracy. Social Text, 25/26: 56-80.

Garnett, Nicole Stelle (20I2). Managing the urban commons, U. Pa. L. Rev. I60, 20I2: 1995-2027.

Hardt, Michael and Negri, Antonio (2009). Commonwealth, Cambridge, MA: Belknap Press of Harvard University.

Harvey, David (2003). The new imperialism, New York: Oxford University Press.

Harvey, David (2007). Habermas and Foucault: Deliberative democracy and strategic state analysis, Contemporary Political Theory, 6, 2: 218-245.

Harvey, David (2008). The right to the city, New Left Review, 53: 23-40.

Harvey, David (20II). The future of the commons, Radical History Review, 109.

Harvey, David (2012). Rebel cities: From the right to the city to the urban revolution, New York: Verso Books.

Hodkinson, Stuart (2012). The new urban enclosures, City, 16, 5: 500-518.

Kristjansdottir, Sigridur \& Sveinsson, Jon Runar (2016). Phantom suburbs out of the ashes, in Gromark, S., Ilmonen, M., Paadam, K. \& Støa, E. (eds.) Ways of residing in transformation: Interdisciplinary perspectives, Farnham: Ashgate, 242-259.

Lee, Shin and Webster, Chris (2006). Enclosure of the urban commons. Geojournal, 66: 27-42.

Lefebvre, Henri (1991 [1974]). The production of space, Oxford: Blackwell.

Lefebvre, Henri (1996). Writings on cities, Cambridge, MA: Blackwell.

Low, Setha (2006). How private interests take over public space: zoning, taxes, and incorporation of gated communities, in Politics of public space, eds. S. Low and N. Smith, New York: Routledge, 8I-104.

Low, Setha and Smith, Neil (eds) (2006). Politics of public space, New York: Routledge.

Manfredini, Manfredo (20I7). The augmented meta-public space: Interpreting emerging transductive territories in enhanced centres of consumption, The Journal of Public Space, 2, 3: I II-I28.

Manfredini, Manfredo (2019), Simulation, Control and Desire: Urban Commons and Semi-Public Space Resilience in the Age of Augmented Transductive Territorial Production.

The Journal of PublicSpace, 4, 2: $179-198$.

McQuire, Scott (2008). The media city: Media, architecture and urban space, Los Angeles: Sage.

Miles, Steven and Miles, Malcolm (2004). Consuming cities, New York: Palgrave Macmillan.

Minton, Anna (2012). Ground control: Fear and happiness in the twenty-first century city, London: Penguin. 
Mitchell, Don (1995). The end of public space? People's Park, definitions of the public, and democracy. Annals of the Association of American Geographers, 85: 108-133.

Mitchell, Don (2003). The right to the city: Social justice and the fight for public space, New York: Guilford

Mitchell, Don (2017). People's Park again: On the on-going history of the end of public space, Environment and Planning A, 49: 503-518.

Mouffe, Chantal (1999). Deliberative democracy or agonistic pluralism? Social Research, 6, 3: 745758.

Mouffe, Chantal (2008). Public spaces and democratic politics. In Highrise-common ground. Art and the Amsterdam Zuidas area, ed. J. Boomgaard, Amsterdam, Netherlands: Valiz, I35-I56.

Purcell, Mark (2002). Excavating Lefebvre: The right to the city and its urban politics of the inhabitant. GeoJournal, 58, 2-3: 99-108.

Purcell, Mark (20I4). Possible worlds: Henri Lefebvre and the Right to the City, Journal of Urban Affairs, 36, I: $|4|-154$.

Sennett, Richard (1977). The fall of public man, New York: Knopf.

Sennett, Richard (2008). Reflections on the public realm, in A Companion to the City, eds. Gary Bridge and Sophie Watson, Chichester: Wiley-Blackwell,380-387.

Sennett, Richard (2018). The open City, in The Quito Papers and the New Urban Agenda, eds. UNHabitat, Richard Sennett, Richard Burdett \& Saskia Sassen, Abingdon, Oxon: Taylor and Francis, 90-95.

Soja, Edward (2010). Seeking spatial justice, Minneapolis: University of Minnesota Press.

Sorkin, Michael (1992). Variations on a theme park: The new American city and the end of public space, New York: Hill and Wang.

Stanek, Lukasz (20I I). Henri Lefebvre on space, Minneapolis: University of Minnesota Press.

Susser, Ida and Tonnelat, Stéphane (2013). Transformative cities: The three urban commons, Focaal, 2013, 66: 105-121.

United Nations (2017). New Urban Agenda: Quito Declaration on Sustainable Cities and Human Settlements for All, adopted at United Nations Conference on Housing and Sustainable Urban Development - Habitat III Quito, Ecuador, October 2016.

Villa, Dana (1992). Postmodernism and the public sphere, American Political Science Review, 86: 712721 .

Williams, Miriam J. (2018). Urban commons are more-than-property, Geographical Research, 56, I: 16-25.

To cite this article:

Manfredini, M. (2019). Urban Commons and the Right to the City. The Journal of Public Space, 4(4), I-4, DOI 10.3289I/jps.v4i4.I23 I 